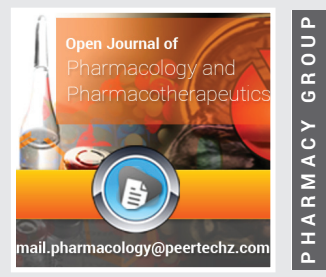

\section{Rheumatoid arthritis:}

\section{Treatment evolution over the}

\section{years}

\section{Eleftherios Pelechas ${ }^{1 *}$ and Panagiota Karagianni ${ }^{2}$}

'University of loannina, School of Medicine, Department of Internal Medicine, Division of Rheumatology

${ }^{2}$ University of Ioannina, School of Medicine, Department of Clinical Microbiology
Received: 23 February, 2020

Accepted: 15 May, 2020

Published: 16 May, 2020

*Corresponding author: Eleftherios Pelechas, PhD, MSc, Mac, University of loannina, Greece, School of Medicine, Department of Internal Medicine, Division of Rheumatology, Tel: +302651099755;

E-mail: pelechas@doctors.org.uk

Keywords: Rheumatoid arthritis; Biologics; Disease modifying anti-rheumatic drugs; Personalized medicine; Treatment evolution

https://www.peertechz.com

Check for updates

\section{Introduction}

Rheumatoid arthritis (RA) is a systemic, inflammatory autoimmune disorder affecting approximately $0.5-1 \%$ [1] of the general population. It is characterized by inflammation and proliferation of the synovial lining, leading to destructive changes within the synovial-lined joints [2], especially if left untreated. Patients suffering from RA, usually complain about pain and swelling of the affected joints as well as morning stiffness in and around the joints, lasting at least 1 hour before maximal improvement [3]. As pain and stiffness are the cardinal symptoms, RA has a substantial impact on the quality of life (QoL) and patients should be regularly assessed and managed appropriately [4]. In addition, extra-articular manifestations are not infrequent. Among them, pericarditis, pleuritis, and cutaneous vasculitis are the most prevalent, but others such as neuropathy, scleritis, and glomerulonephritis may occur [5]. In order to better classify and manage earlier those patients, the 2010 Rheumatoid arthritis classification criteria have emerged [6] substituting the ones dating back to 1987 [7]. Since then, there is no doubt that in the field of rheumatology it has been achieved astonishing progress in the understanding and management of the rheumatic diseases including RA [8]. The progress has been achieved not only by the emergence of the newer drugs [9] but also the treatment strategies [10]. On the other hand, there are still unmet needs [11] despite all this progress and this subject is still a matter of debate [12] of what we are doing wrong in order to achieve complete remission in those patients [13].

\section{The drug evolution in RA}

Drug therapy has been evolved dramatically in the last 50 years. Rheumatologists used to treat their patients with salicylates, non-steroidal anti-inflammatory drugs (NSAIDS), and corticosteroids (cs), since the advent of the conventional synthetic disease-modifying anti-rheumatic drugs (csDMARDs), biologic (b) DMARDS and lately the targetedsynthetic (ts) DMARDs.

The effectiveness of the salicylic acid in rheumatic disorders was first reported independently by two German physicians (Stricher and Reiss) in 1876, while in 1897, it had gained worldwide recognition in the treatment of pain [14]. However, the mechanism of action of NSAIDs remained elusive until the early 1960's when John Vane discovered it in 1971 increasing our ability to develop novel NSAID-therapies [15,16]. The real breakthrough in the treatment of RA has happened with the discovery of cortisone, a mysterious humour that improved RA with the name "substance X" [17]. In 1948, the first patient with $\mathrm{RA}$ received the "substance $\mathrm{X}$ " or later the "compound $\mathrm{E}$ " in the form of intramuscular injections of $50 \mathrm{mg}$, twice daily. On day 4, her pain and stiffness were gone and by day 7 she was able to go shopping. The so-called "substance X" or "compound E" later known as cortisone, led Philip Hench and Edward Kendall to receive the Nobel Prize in medicine and Physiology in 1950 [18]. Nowadays, the adverse reactions of NSAIDs and cs are wellknown and should not be given for a long period of time $[19,20]$. Some years later, in 1962, Black et al, reported positive results with methotrexate (MTX) in RA and psoriatic arthritis (PsA) patients [21]. Since then, MTX is the most studied csDMARD with a safe and effective profile in the treatment of RA patients [22]. But, MTX alone does not typically results in drug-free remission and there is a significant proportion of patients that do not tolerate the side effects of the treatment. For the former, a combination of cSDMARDs with or without cs has been tried [23] whereas for the latter switching to a different csDMARD was 
the only solution [24]. The quest for better treatment options with less side effects and stronger therapeutic potency led to the discovery of the bDMARDs. In the late 1990s, the introduction of biologic targeted therapies $[25,26]$ and in the last decade the development of the tsDMARDs [27] changed significantly the lives of RA patients. Biosimilars have also appeared after the expiration of the bio-originals' patent giving the opportunity to treat more patients by decreasing the treatment costs [2830] Rituximab (RTX), a chimeric monoclonal antibody that targets the CD20 molecule expressed on the surface of B cells has been also approved for the treatment of RA patients that do not respond adequately to bDMARDs [31].

\section{The evolution of treatment strategies in RA}

Treatment strategies have also changed over those years. This evolution gone hand by hand with the discovery of new drugs. At the very beginning, the RA patient has been treated symptomatically using monotherapy regimens, bed rest and physical therapy. Later, and as the therapeutic options grew with the application of the csDMARDs more than one drugs had been employed (dual therapy and triple therapy - combination therapy) [32]. Then, other regimens have been tried such as the step-up therapy or aggressive schemes with high doses of cs and step-down afterwards with satisfactory results [33-35]. The main target of all these regimens was low disease activity or remission. Finally, in the era of the csDMARDs, bDMARDs and tsDMARDs more and more patients enjoy a life free of pain being in remission or in a low disease activity state In the future we may be able to personalise treatments in order to achieve even better results.

\section{References}

1. Drosos AA (2004) Epidemiology of rheumatoid arthritis. Autoimmune Rev 3(Suppl 1): S20-22. Link: https://bit.ly/2AynPek

2. Sweeney SE, Firestein GS (2004) Rheumatoid arthritis: regulation of synovial inflammation. Int J Biochem Cell Biol 36: 372-378. Link https://bit.ly/2Z69pfG

3. Grassi W, De Angelis R, Lamanna G, Cervini C (1998) The clinical features of rheumatoid arthritis. Eur J Radiol 27(Suppl 1): S18-24. Link: https://bit.ly/3fPJLBX

4. Matcham F, Scott IC, Rayner L, Hotopf M, Kingsley GH, et al. (2014) The impact of rheumatoid arthritis on quality-of-life assessed using the SF-36 a systematic review and meta-analysis. Semin Arthritis Rheum 44: 123-130. Link: https://bit.ly/362nowV

5. Turesson C, O'Fallon WM, Crowson CS, Gabriel SE, Matteson EL (2003) Extra-articular disease manifestations in rheumatoid arthritis: incidence trends and risk factors over 46 years. Ann Rheum Dis 62: 722-727. Link: https://bit.ly/3fNlj2V

6. Aletaha D, Neogi T, Silman AJ, Funovits J, Felson DT, et al. (2010) 2010 Rheumatoid arthritis Classification criteria. An American College of Rheumatology\European League Against Rheumatism collaborative initiative. Ann Rheum Dis 69: 1580-88. Link: https://bit.ly/2Z3qAP0

7. Arnett FC, Edworthy SM, Bloch DA, McShane DJ, Fries JF, et al. (1998) The American Rheumatism Association 1987 revised criteria for the classification of rheumatoid arthritis. Arthritis Rheum 31: 315-324. Link: https://bit.ly/2Z9jwjK

8. Aggarwal D, Abraham S (2016) Rheumatoid arthritis treatments: a historical perspective. JSM Arthritis 1: 1011
9. Conti F, Ceccarelli F, Massaro L, Cipriano E, Franco M, et al. (2013) Biological therapies in rheumatic diseases. Clin Ther 164: e413-28. Link: https://bit.ly/3cxiW3f

10. Demoruelle MK, Deane KD (2012) Treatment strategies in early rheumatoid arthritis and prevention of rheumatoid arthritis. Curr Rheumatol Rep 14: 472 480 Link: https://bit.ly/365LWg7

11. Kaltsonoudis E, Pelechas E, Voulgari PV, Drosos AA (2019) Unmet needs in the treatment of rheumatoid arthritis An observational study and a real-life experience from a single university center. Semin Arthritis Rheum 48: 597602. Link: https://bit.ly/3fS6fC8

12. Kaltsonouids E, Pelechas E, Voulgari PV, Drosos AA (2019) Comment on: Assessments of the unmet need in the management of patients with rheumatoid arthritis: analyses from the NOR-DMARD registry. Rheumatology (Oxford) 58: 1883-1884. Link: https://bit.ly/2Lvs2/1

13. Drosos AA, Pelechas E, Voulgari PV (2019) Rheumatoid arthritis Treatment. A back to the drawing board project or high expectations for low unmet needs? J Clin Med 8: E1237 Link: https://bit.ly/2WZAb6T

14. Hedner T, Everts B (1998) The early clinical history of salicylates in rheumatology and pain. Clin Rheumatology 17: 17-25. Link: https://bit.ly/3cFji8a

15. Vane JR (1971) Inhibition of prostaglandin synthesis as a mechanism of action for aspirin-like drugs. Nat New Biol 43: 232-235. Link: https://bit.ly/2Zc7arg

16. Vane JR (1976) The mode of action of aspirin and similar compounds. J Allergy Clin Immunol 58: 691-712. Link: https://bit.ly/2WCLv9X

17. Hench PS (1949) Potential reversibility of rheumatoid arthritis. Ann rheum Dis 8: 90-96. Link: https://bit.ly/2zHnrcW

18. Hench PS (1951) Reminiscences of the Nobel Festival, 1950. Proc Staff Meet Mayo Clin 26: 424-437. Link: https://bit.ly/3bB10mY

19. Walsh LJ, Wong CA, Oborne J, Cooper S, Lewis SA, et al. (2001) Adverse effects of oral corticosteroids in relation to dose in patients with lung disease. Thorax 56: 279-284. Link: https://bit.ly/2yS0jso

20. Pelechas E, Memi T, Gerolymatou N, Zouzos G, Karagianni P (2019) Corticosteroids as a cause of catastrophic rheumatoid arthritis. Fortune Rheumatol 1: 015-017

21. Black RL, O'Brien WM, Van Scott EJ, Auerbach R, Eisen AZ, et al. (1964) Methotrexate therapy in psoriatic arthritis; double-blind study on 21 patients. JAMA 189: 743-747. Link: https://bit.ly/2T6shaw

22. Weinblatt ME (2013) Methotrexate in Rheumatoid Arthritis: a quarter century of development. Trans Am Clin Climatol Assoc 124: 16-26. Link: https://bit.ly/3fUy3py

23. O'Dell JR, Haire CE, Erikson N, Drymalski W, Palmer W, et al. (1996) Treatmen of rheumatoid arthritis with methotrexate alone, sulfasalazine and hydroxychloroquine, or a combination of all three medications. N Engl J Med 334: 1287-1291. Link: https://bit.ly/3byl60V

24. Kremer JM (1995) The changing face of therapy for rheumatoid arthritis Rheum Dis Clin North Am 21: 845-852. Link: https://bit.ly/2Aypxwg

25. Pelechas E, Voulgari PV, Drosos AA (2019) Clinical evaluation of the safety, efficacy and tolerability of sarilumab in the treatment of moderate to severe rheumatoid arthritis. Ther Clin Risk Manag 15: 1073-1079. Link: https://bit.ly/2WZHQ54

26. Pelechas E, Voulgari PV, Drosos AA (2019) Golimumab for rheumatoid arthritis. J Clin Med 8: E387. Link: https://bit.ly/2T9deNq

27. Pelechas E (2017) JAK inhibitors: a promising direction for treating rheumatoid arthritis. Int J Pharm Sci Dev Res 3: 029. Link: https://bit.ly/2y6UIOp 
28. Pelechas E, Drosos AA (2019) Etanercept biosimilar SB-4. Expert Opin Bio Ther 19: 173-179. Link: https://bit.ly/2Ayq954

29. Pelechas E, Voulgari PV, Drosos AA (2018) ABP 501 for the treatment of rheumatoid arthritis. Expert Opin Biol Ther 18: 317-322. Link: https://bit.ly/2ZkboNJ

30. Pelechas E, Voulgari PV, Drosos AA (2017) Sirukumab: a promising therapy for rheumatoid arthritis. Expert Opin Biol Ther 17: 755-763. Link: https://bit.ly/2zE2tvA

31. Mok CC (2014) Rituximab for the treatment of rheumatoid arthritis: an update. Drug Des Devel Ther 8: 87-100. Link: https://bit.ly/3byOp3H

32. Saunders SA, Capell HA, Stirling A, Vallance R, Kincaid W, et al. (2008) Triple therapy in early active rheumatoid arthritis: A randomized, single-blind, controlled trial comparing step-up and parallel treatment strategies. Arthritis Rheum 58: 1310-1317. Link: https://bit.ly/3fT00hk

33. Steunebrink LMM, Versteeg GA, Vonkeman HE, ten Klooster PM, Kuper HH, et al. (2016) Initial combination therapy versus step-up therapy in treatment to the target of remission in daily clinical practice in early rheumatoid arthritis patients: results from the DREAM registry. Arthritis Res Ther 18: 60. Link: https://bit.ly/2LzUNNM

34. Boers M, Verhoeven AC, Markusse HM, van de Laar MA, Westhovens $R$, et al. (1997) Randomised comparison of combined step-down prednisolone, methotrexate and sulphasalazine with sulphasalazine alone in early rheumatoid arthritis. Lancet 350: 309-318. Link: https://bit.ly/3cCNyjN

35. Boers M (2011) The COBRA trial 20 years later. Clin Exp Rheumatol 29 (Supp 68): S46-51. Link: https://bit.ly/3bDjpQf
Discover a bigger Impact and Visibility of your article publication with

Peertechz Publications

\section{Highlights}

* Signatory publisher of ORCID

* Signatory Publisher of DORA (San Francisco Declaration on Research Assessment)

* Articles archived in worlds' renowned service providers such as Portico, CNKI, AGRIS, TDNet, Base (Bielefeld University Library), CrossRef, Scilit, J-Gate etc.

* Journals indexed in ICMJE, SHERPA/ROMEO, Google Scholar etc.

- OAI-PMH (Open Archives Initiative Protocol for Metadata Harvesting)

* Dedicated Editorial Board for every journal

* Accurate and rapid peer-review process

* Increased citations of published articles through promotions

* Reduced timeline for article publication

Submit your articles and experience a new surge in publication services

(https://www.peertechz.com/submission).

Peertechz journals wishes everlasting success in your every endeavours.

Copyright: (C) 2020 Pelechas E, et al. This is an open-access article distributed under the terms of the Creative Commons Attribution License, which permits unrestricted use, distribution, and $r$ eproduction in any medium, provided the original author and source are credited. 